\title{
Effect of forage type in the ovine diet on the nutritional profile of sheep milk cheese fat
}

\author{
E. Renes, ${ }^{1}$ P. Gómez-Cortés, ${ }^{2}$ M. A. de la Fuente, ${ }^{2}$ D. Fernández, ${ }^{1}$ M. E. Tornadijo, ${ }^{1}$ and J. M. Fresno ${ }^{1 *}$ \\ ${ }^{1}$ Department of Food Hygiene and Technology, Faculty of Veterinary Science, University of León, 24071, León, Spain \\ ${ }^{2}$ Instituto de Investigación en Ciencias de la Alimentación (CIAL, CSIC-UAM), Universidad Autónoma de Madrid, Nicolás Cabrera, 9, 28049, \\ Madrid, Spain
}

\section{ABSTRACT}

The high nutritional value of sheep milk can be advantageous in the manufacture of cheese, and fat plays an important role in sheep cheese properties. The aim of this study was to investigate the effect of feeding common hay or silage diets used in commercial farms on the nutritional value of sheep cheese fat. We also monitored the effect of cheese ripening period on the fatty acid profile. Cheeses were produced from milk of sheep fed hay and silage diets from 8 farms, on 4 separate occasions (February, May, August, and November) over a 1-yr period. Eighty-four individual fatty acids were determined and identified by gas chromatography. Ripening time (100 and 180 d) significantly reduced moisture, acidity, and water activity of cheeses but did not affect the fatty acid content. However, hay feeding, compared with silage feeding, led to cheeses with 1.5- and 1.3-fold higher contents of vaccenic acid and conjugated linoleic acid, without detrimental changes in saturated and n-3 (omega-3) fatty acid composition. Hay forages could be a low-cost alternative for producing cheese with a fatty acid profile suitable for human health, which is an aspect of great interest to the food industry.

Key words: fatty acid, hay, sheep cheese, silage

\section{INTRODUCTION}

Sheep milk has high concentrations of protein, fat, minerals, and vitamins compared with milks of other domestic species (Balthazar et al., 2017). Most of the sheep milk produced is used to manufacture cheese, which represents a significant percentage of the world agricultural trade. Cheese contains lipid compounds that can improve consumers' health, such as CLA, oleic acid, and vaccenic acid (VA; Field et al., 2009; Sales-Campos et al., 2013; Gómez-Cortés et al., 2018).

Received June 4, 2019.

Accepted September 1, 2019.

*Corresponding author: jmfreb@unileon.es
Therefore, the design of strategies to increase the content of these bioactive compounds in cheese has special interest.

The effect of post-milking factors on the fatty acid profile remains unclear. In cheeses, the application of heat and the use of different fermentation cultures or ripening periods can modulate the levels of bioactive fatty acids in the final foodstuff. Lin et al. (1999) recorded the highest CLA levels in Cheddar cheese after 3 mo of ripening, and Buccioni et al. (2010) reported that the total CLA content in Pecorino cheese increased by more than $10 \%$ during ripening. In a recent study (Renes et al., 2019), the presence of Lactobacillus plantarum and Lactobacillus casei ssp. casei CLA-producing strains led to a decrease in SFA content and to higher levels of VA, CLA, and n-3 (omega-3) fatty acids, compared with control cheese. In contrast, other research has not found any significant effects of manufacturing on the fatty acid profiles of different cheese varieties (Ryhänen et al., 2005; Gómez-Cortés et al., 2009a; Bodas et al., 2010).

Numerous studies have noted that the ruminant diet is another factor influencing milk fat quality (Shingfield et al., 2013; Nudda et al., 2014). Pasture-based diets have a greater influence on sheep milk fatty acid composition than diets based on conserved forages and concentrates (Addis et al., 2005; Cabiddu et al., 2005; Gómez-Cortés et al., 2009b; Cividini and Simčič, 2015). However, conserved forages form the major part of sheep diets in most farming systems. The nature and composition of forages influence rumen biohydrogenation pathways and affect the milk fatty acid profile (Buccioni et al., 2012). Glasser et al. (2013) stated that the main factors influencing the fatty acid content of forages were species, vegetation stage, conditions of conservation, and $\mathrm{N}$ fertilization. For example, bad drying conditions during haymaking led to a decrease in $\mathrm{C}_{18: 3}$ fatty acids, and extensive lipolysis during ensiling can enhance the rate of PUFA biohydrogenation in the rumen (Glasser et al., 2013). Another aspect related to conservation methods is that forage wilting generates mechanical damage to plant tissues and allows 
air access, which leads to extensive oxidation of PUFA (Kalač and Samková, 2010). In this context, Aii et al. (1988) observed higher oxidative losses of $\alpha$-linolenic acid in Lolium multiflorum hay than in Lolium multiflorum silage.

Dewhurst et al. (2006) noted that forage provides a low-cost option to modify milk fat with a view to improving the health of consumers, which is an aspect of great interest to the food industry. However, to the best of our knowledge, little information is available on the effect of forage conservation methods used for sheep feeding on the fatty acid profile of cheese made from the milk obtained. Therefore, this study had 2 aims: (1) to investigate the effect of feeding hay and silage diets used in commercial farms on the nutritional value of sheep cheese fat; and (2) to determine the effect of ripening period on the sheep cheese fatty acid profile.

\section{MATERIALS AND METHODS}

\section{Animals and Diets}

Eight commercial farms of the Assaf sheep breed, located in Castilla and León (Spain), were selected for the present study. Each flock had between 400 and 900 sheep. Throughout this study, the 8 flocks received a typical milking ration with a forage:concentrate ratio of 50:50. Four flocks were fed with $60 \%$ common vetch (Vicia sativa) hay and the other 4 flocks were fed with the same percentage of common vetch but in the form of silage. The hay and silage were made from common vetch grown in the same field. The ingredients and the chemical composition of the 2 diets are given in Table 1 .

\section{Sampling and Sheep Cheese Making}

Bulk tank raw milk (evening and morning milks) was collected from each flock for cheese manufacture on 4 separate occasions over a 1-yr period: February, May, August, and November. Cheesemaking trials (8 cheese batches $\times 3$ replicates $\times 4$ mo) were performed in the second week of each collection month on the pilot scale (Institute of Food Science and Technology, University of León, Spain).

The cheesemaking procedure was as follows: $100 \mathrm{~L}$ of milk was pasteurized at $72^{\circ} \mathrm{C}$ for $15 \mathrm{~s}$. Calcium chloride $(0.2 \mathrm{~g} / \mathrm{L})$ and a starter culture $(1 \%, \mathrm{vol} / \mathrm{vol}$; Choozit LYO MA 011; DuPont, Copenhagen, Denmark) composed of Lactococcus lactis ssp. lactis and Lactococcus lactis ssp. cremoris were added. After 30 min, chymosin [Chy-Max Extra, 100\% chymosin, 600 international milk-clotting units (IMCU) $/ \mathrm{mL}$; Chr. Hansen SL, Madrid, Spain] was added at a rate of $0.05 \mathrm{~mL} / \mathrm{L}$ of milk (diluted 1:20 with deionized water). After 40 to 45 min, the curd was cut to rice grain size and the whey was drained off. The curd was transferred to cylindrical molds (15 cm high, $21 \mathrm{~cm}$ in diameter), which were pressed for $2 \mathrm{~h}$. Then, cheeses were salted by immersion (brine density $18^{\circ}$ Baumé, $8^{\circ} \mathrm{C}$, and $\mathrm{pH} 5.4$ ) for $17 \mathrm{~h}$. Finally, the cheeses were taken to a ripening chamber, where they remained at $10^{\circ} \mathrm{C}$ and at 80 to $85 \%$ relative humidity for $180 \mathrm{~d}$.

Samples (each sample corresponded to a whole cheese of $3.25 \mathrm{~kg}$ ) were taken from each cheese batch after 100 and $180 \mathrm{~d}$ of ripening. Samples were ground, vacuum packed, and stored in a freezer $\left(-30^{\circ} \mathrm{C}\right)$ until fatty acid analysis. Physicochemical analyses were carried out on fresh samples. All analyses were performed in triplicate.

\section{Analytical Methods}

The 2 diets were analyzed for DM (ISO, 1999), ash (ISO, 2002), CP (Thiex et al., 2002), fat (AOAC, 1990a), and NDF and ADF (Van Soest et al., 1991).

The $\mathrm{pH}$ and titratable acidity of cheese batches were determined according to standard 14.022 (AOAC, 1980a,b). Water activity $\left(\mathbf{a}_{\mathrm{w}}\right)$ was analyzed instrumentally using an Aqua Lab Dew Point Analyzer CX-2 (Decagon Devices, Pullman, WA). Total solids, $\mathrm{NaCl}$,

Table 1. Ingredients, chemical composition, and fatty acid profile of hay and silage diets

\begin{tabular}{lcc}
\hline & \multicolumn{2}{c}{ Type of forage diet } \\
\cline { 2 - 3 } Item & Hay & Silage \\
\hline Ingredient, g/kg & \multicolumn{2}{c}{} \\
Common vetch silage & - & 300 \\
Common vetch hay & 300 & - \\
Alfalfa & 200 & 200 \\
Corn & 150 & 150 \\
Barley & 160 & 160 \\
Soybean meal & 80 & 80 \\
Oats & 90 & 90 \\
Green peas & 10 & 10 \\
Rapeseed & 5 & 5 \\
Mineral-vitamin premix & 5 & 5 \\
Nutrient, g/kg & & \\
DM & 894 & 896 \\
Ash & 68 & 39 \\
CP & 161 & 162 \\
Fat & 26 & 28 \\
NDF & 272 & 277 \\
ADF & 173 & 174 \\
Fatty acids, g/kg & \multicolumn{2}{c}{} \\
C14:0 & 0.09 & 0.08 \\
C16:0 & 3.28 & 2.86 \\
C16:1 & 0.05 & 0.05 \\
C18:0 & 0.43 & 0.39 \\
C18:1 & 5.08 & 4.81 \\
C18:2 $18: 3$ & 8.24 & 6.93 \\
C $>20$ & 1.93 & 2.63 \\
& 0.34 & 0.38 \\
\hline
\end{tabular}


fat, and protein contents were determined according to standards 004 (FIL-IDF, 2004), 935.43 (AOAC, 1990b), 221 (FIL-IDF, 2008), and 20-1 (FIL-IDF, 2001), respectively.

Cheese fat extraction was carried out using $n$-pentane after grinding the sample with a mixture of sand and sodium sulfate (Bodas et al., 2010). Fatty acids were derivatized to methyl esters (FAME) by base-catalyzed methanolysis of glycerides with $\mathrm{KOH}$ in methanol (Bichi et al., 2012). The FAME were analyzed by GC using 2 different columns, CP-Sil $88(100 \mathrm{~m} \times 0.25 \mathrm{~mm}$ i.d.; Varian, Palo Alto, CA) and SLB-IL111 capillary column $(100 \mathrm{~m} \times 0.25 \mathrm{~mm}$ i.d.; Supelco, Bellefonte, PA). The detailed GC methods as well as the identification and quantification of FAME were as previously reported (de la Fuente et al., 2015).

\section{Statistical Analysis}

Statistical analysis of the experimental data was performed using SPSS v.23 (SPSS Inc., Chicago, IL). The fatty acid and physicochemical variables were tested for the assumption of normality using the Lillieforscorrected Kolmogorov-Smirnov test and for homoscedasticity using the Levene test. Subsequently, data were analyzed using a general linear model of ANOVA to investigate the effect of the type of forage feeding (hay, silage), ripening time $(100,180 \mathrm{~d})$, and the interaction between them. The month of milk collection for cheesemaking was considered a repeated factor and the interactions were removed from the model because they were not statistically significant $(P>0.05)$. Therefore, Student's $t$-test was applied at a $5 \%$ significance level to compare sheep cheeses manufactured with milk from commercial flocks fed with different types of forage at 100 and $180 \mathrm{~d}$ of ripening.

\section{RESULTS AND DISCUSSION}

\section{Physicochemical Composition of Sheep Milk Cheeses}

Table 2 shows average values for the physicochemical parameters of cheeses. None of these parameters analyzed in the cheeses showed significant differences $(P>$ $0.05)$ in relation to the type of forage included in the sheep diet. This could be because of the compositional homogeneity observed between the 2 diets studied (Table 1). In addition, the use of bulk tank milk for cheesemaking reduced possible differences in chemical composition of milk associated with individuals. The physicochemical parameters of each cheese variety is determined mainly by the cheesemaking process and it was standardized in the current study. This fact could explain the absence of differences $(P>0.05)$ in the physicochemical composition of cheeses manufactured with milk from sheep fed hay or silage diets.

The differences observed $(P \leq 0.05)$ in the physicochemical parameters were established by ripening time. The values for moisture, titratable acidity, $\mathrm{pH}$, and $\mathrm{a}_{\mathrm{w}}$ parameters decreased significantly during ripening, reaching final average values at $180 \mathrm{~d}$ of $31.60 \%, 1.54 \%$, 5.19 , and 0.920 , respectively. However, the salt:moisture ratio increased, with average values in the cheese of 53 and $67 \mathrm{~g}$ of salt $/ \mathrm{kg}$ of moisture after 100 and $180 \mathrm{~d}$ of ripening, respectively. These high values for the salt:

Table 2. $\mathrm{pH}$, titratable acidity, water activity $\left(\mathrm{a}_{\mathrm{w}}\right)$, moisture, salt/moisture, and fat and protein concentrations of cheeses (made with bulk tank milk from sheep fed hay or silage) during 100 and $180 \mathrm{~d}$ of ripening ${ }^{1}$

\begin{tabular}{|c|c|c|c|c|c|}
\hline \multirow[b]{2}{*}{ Physicochemical parameter } & \multirow[b]{2}{*}{ Type of forage } & \multicolumn{2}{|c|}{ Ripening time } & \multicolumn{2}{|c|}{$P$-value } \\
\hline & & $100 \mathrm{~d}$ & $180 \mathrm{~d}$ & Type of forage & Ripening time \\
\hline$\overline{\mathrm{pH}}$ & Silage & $5.28 \pm 0.14$ & $5.19 \pm 0.08$ & & \\
\hline \multirow{2}{*}{$\begin{array}{l}\text { Titratable acidity, g of lactic acid } / \mathrm{kg} \\
\text { of TS }\end{array}$} & Hay & $17.44 \pm 1.39$ & $15.15 \pm 1.52$ & NS & $* * *$ \\
\hline & Silage & $18.15 \pm 1.30$ & $15.67 \pm 1.41$ & & \\
\hline$a_{w}$ & Hay & $0.949 \pm 0.008$ & $0.918 \pm 0.005$ & NS & * \\
\hline Moisture, $\mathrm{g} / \mathrm{kg}$ of cheese & Silage & $347.03 \pm 17.12$ & $319.24 \pm 19.56$ & & \\
\hline \multirow[t]{2}{*}{ Salt/moisture, $\mathrm{g}$ of salt $/ \mathrm{kg}$ of moisture } & Hay & $53.71 \pm 0.86$ & $67.22 \pm 1.33$ & NS & ** \\
\hline & Silage & $53.35 \pm 0.82$ & $66.83 \pm 1.21$ & & \\
\hline \multirow[t]{2}{*}{ Fat, $\mathrm{g} / \mathrm{kg}$ of $\mathrm{TS}$} & Hay & $571.03 \pm 23.11$ & $570.05 \pm 22.71$ & NS & NS \\
\hline & Silage & $574.16 \pm 26.61$ & $570.40 \pm 21.34$ & & \\
\hline \multirow[t]{2}{*}{ Protein, $\mathrm{g} / \mathrm{kg}$ of TS } & Hay & $357.41 \pm 20.33$ & $357.72 \pm 11.22$ & NS & NS \\
\hline & Silage & $354.17 \pm 21.31$ & $356.34 \pm 12.07$ & & \\
\hline
\end{tabular}

${ }^{1}$ Results expressed as mean values $\pm \mathrm{SD}, \mathrm{n}=144$.

${ }^{*} P \leq 0.05 ;{ }^{* *} P \leq 0.01 ;{ }^{* * *} P \leq 0.001 ;{ }^{\text {NS }} P>0.05$. 
moisture ratio and the low values of $a_{w}$ could be useful to inhibit the development of pathogenic bacteria (Thomas and Pearce, 1981).

The decrease observed in titratable acidity values of cheeses between 100 and $180 \mathrm{~d}$ of ripening could be due to the metabolism of lactic acid by the cheese microbiota (McSweeney and Sousa, 2000). It could also be explained by the high salt:moisture values detected, which could inhibit the activity of lactic acid bacteria (Agarwal et al., 2008). Finally, the protein and fat contents of the cheeses remained constant during ripening, reaching values of 35.70 and $57.01 \%$, respectively, of total solids after $180 \mathrm{~d}$.

\section{Cheese Fatty Acid Profile}

In the present study, 84 fatty acids were detected and quantified by GC (Tables 3,4 , and 5 ). The time of ripening did not significantly modify $(P>0.05)$ most of the fatty acids monitored. The 2 ripening times (100 and $180 \mathrm{~d}$ ) were chosen because they are the 2 time points when this type of cheese is usually marketed. Some studies have reported that ripening time does not affect the fatty acid profile of cheese (Gómez-Cortés, et al., 2009a; Bodas et al., 2010; dos Santos et al., 2012). Nudda et al. (2005), after examining a large number of milk and cheese samples, observed that the CLA levels in cheese reflect the composition of the raw milk used. Renes et al. (2019) indicated that this could be because the cheese matrix provides stability to the bioactive fatty acids, perhaps preventing oxidation of these compounds during ripening.

Manipulation of the fatty acid profile of milk through nutritional strategies to improve the fat content of dairy products is an important goal for the dairy industry. Variability in pasture quality and availability throughout the year has led to the use of preserved forages as the main source of feedstuffs in dairy sheep

Table 3. Saturated fatty acid composition ( $\mathrm{g} / 100 \mathrm{~g}$ of total FAME) of cheese fat from sheep fed with hay or silage

\begin{tabular}{|c|c|c|c|c|c|}
\hline \multirow[b]{2}{*}{ Variable } & \multicolumn{2}{|c|}{ Type of forage diet } & \multirow[b]{2}{*}{$\mathrm{SED}^{1}$} & \multicolumn{2}{|c|}{$P$-value ${ }^{2}$} \\
\hline & Hay & Silage & & Type of forage & Ripening time \\
\hline Total SFA & 71.12 & 72.06 & 0.519 & NS & NS \\
\hline$\Sigma$ Non-BCFA $^{3}$ & 69.34 & 70.27 & 0.501 & NS & NS \\
\hline $4: 0$ & 3.94 & 3.92 & 0.087 & NS & NS \\
\hline $5: 0$ & 0.03 & 0.03 & 0.002 & NS & NS \\
\hline $6: 0$ & 2.98 & 2.97 & 0.052 & NS & NS \\
\hline $7: 0$ & 0.04 & 0.04 & 0.002 & NS & NS \\
\hline $8: 0$ & 2.58 & 2.60 & 0.058 & NS & NS \\
\hline 9:0 & 0.06 & 0.05 & 0.003 & NS & NS \\
\hline 10:0 & 7.39 & 7.51 & 0.212 & NS & NS \\
\hline 11:0 & 0.06 & 0.06 & 0.003 & NS & NS \\
\hline $12: 0$ & 4.05 & 4.24 & 0.133 & NS & NS \\
\hline 13:0 & 0.07 & 0.07 & 0.003 & NS & NS \\
\hline 14:0 & 9.91 & 10.22 & 0.227 & NS & NS \\
\hline $15: 0$ & 0.89 & 0.88 & 0.026 & NS & NS \\
\hline $16: 0$ & 25.48 & 25.74 & 0.318 & NS & NS \\
\hline $17: 0$ & 0.65 & 0.64 & 0.021 & NS & NS \\
\hline $18: 0$ & 10.52 & 10.61 & 0.429 & NS & NS \\
\hline $20: 0$ & 0.33 & 0.35 & 0.025 & NS & NS \\
\hline 21:0 & 0.08 & 0.08 & 0.007 & NS & NS \\
\hline $22: 0$ & 0.14 & 0.14 & 0.013 & NS & NS \\
\hline $23: 0$ & 0.07 & 0.08 & 0.009 & NS & NS \\
\hline $24: 0$ & 0.06 & 0.07 & 0.007 & NS & NS \\
\hline$\Sigma$ BCFA & 1.78 & 1.78 & 0.049 & NS & NS \\
\hline $13: 0$ iso & 0.02 & 0.02 & 0.002 & NS & NS \\
\hline 13:0 anteiso & 0.04 & 0.04 & 0.003 & NS & NS \\
\hline 14:0 iso & 0.09 & 0.09 & 0.005 & NS & NS \\
\hline 15:0 iso & 0.23 & 0.24 & 0.009 & NS & NS \\
\hline 15:0 anteiso & 0.40 & 0.38 & 0.010 & NS & NS \\
\hline 16:0 iso & 0.22 & 0.23 & 0.009 & NS & NS \\
\hline 17:0 iso & 0.23 & 0.24 & 0.010 & NS & NS \\
\hline 17:0 anteiso & 0.50 & 0.49 & 0.015 & NS & NS \\
\hline 18:0 iso & 0.06 & 0.06 & 0.002 & NS & NS \\
\hline
\end{tabular}

${ }^{1} \mathrm{SED}=$ standard error of difference. Results as mean values of triplicate determination $(\mathrm{n}=288)$.

${ }^{2}$ Probability of significant effects due to type of forage (hay and silage) and ripening time (100 and $180 \mathrm{~d}$ ).

${ }^{3} \mathrm{BCFA}=$ branched-chain fatty acids.

${ }^{\mathrm{NS}} P>0.05$. 
Table 4. Monounsaturated fatty acid composition (g/100 g of total FAME) of cheese fat from sheep fed with hay or silage

\begin{tabular}{|c|c|c|c|c|c|}
\hline \multirow[b]{2}{*}{ Variable } & \multicolumn{2}{|c|}{ Type of forage } & \multirow[b]{2}{*}{$\mathrm{SED}^{1}$} & \multicolumn{2}{|c|}{$P$-value ${ }^{2}$} \\
\hline & Hay & Silage & & Type of forage & Ripening time \\
\hline Total MUFA & 23.45 & 23.31 & 0.478 & NS & NS \\
\hline$\Sigma$ cis-MUFA & 20.13 & 20.83 & 0.432 & NS & NS \\
\hline $10: 1$ & 0.24 & 0.25 & 0.011 & NS & NS \\
\hline $12: 1$ cis- 11 & 0.06 & 0.07 & 0.004 & NS & NS \\
\hline $14: 1$ cis-9 & 0.16 & 0.17 & 0.012 & NS & NS \\
\hline $16: 1 \mathrm{cis}-7$ & 0.22 & 0.24 & 0.007 & NS & NS \\
\hline $16: 1$ cis- 8 & 0.03 & 0.03 & 0.003 & NS & NS \\
\hline $16: 1$ cis-9 & 0.60 & 0.62 & 0.034 & NS & NS \\
\hline $16: 1$ cis- 10 & 0.08 & 0.07 & 0.004 & NS & NS \\
\hline $16: 1$ cis-11 & 0.02 & 0.03 & 0.002 & NS & NS \\
\hline $16: 1$ cis- 13 & 0.02 & 0.02 & 0.001 & NS & NS \\
\hline 17:1 cis-9 & 0.18 & 0.20 & 0.012 & NS & NS \\
\hline 18:1 cis-9 & 17.06 & 17.80 & 0.415 & NS & NS \\
\hline $18: 1$ cis- 11 & 0.81 & 0.82 & 0.035 & NS & NS \\
\hline $18: 1$ cis- 12 & 0.41 & 0.31 & 0.023 & $* * *$ & NS \\
\hline $18: 1$ cis- 13 & 0.03 & 0.03 & 0.001 & NS & NS \\
\hline $18: 1$ cis-15 & 0.08 & 0.08 & 0.003 & NS & NS \\
\hline $18: 1$ cis- 16 & 0.08 & 0.08 & 0.004 & NS & NS \\
\hline $20: 1$ cis- 11 & 0.04 & 0.04 & 0.002 & NS & NS \\
\hline$\Sigma$ trans-MUFA & 3.32 & 2.48 & 0.170 & $* * *$ & NS \\
\hline $15: 1$ & 0.08 & 0.07 & 0.003 & NS & NS \\
\hline 16:1 trans- 4 & 0.02 & 0.01 & 0.002 & NS & NS \\
\hline $16: 1$ trans -5 & 0.02 & 0.02 & 0.002 & NS & NS \\
\hline $16: 1$ trans- 6 & 0.02 & 0.02 & 0.002 & NS & NS \\
\hline $16: 1$ trans $-7+$ trans -8 & 0.04 & 0.04 & 0.003 & NS & NS \\
\hline 16:1 trans -9 & 0.15 & 0.11 & 0.011 & $* * *$ & NS \\
\hline $16: 1$ trans -10 & 0.04 & 0.03 & 0.002 & NS & NS \\
\hline 18:1 trans -4 & 0.02 & 0.02 & 0.002 & NS & NS \\
\hline $18: 1$ trans -5 & 0.02 & 0.02 & 0.001 & NS & NS \\
\hline $18: 1$ trans $-6+$ trans $-7+$ trans -8 & 0.21 & 0.18 & 0.010 & ** & NS \\
\hline 18:1 trans -9 & 0.22 & 0.20 & 0.011 & * & NS \\
\hline $18: 1$ trans -10 & 0.49 & 0.30 & 0.036 & $* * *$ & NS \\
\hline 18:1 trans-11 $\left(\mathrm{VA}^{3}\right)$ & 1.25 & 0.81 & 0.081 & $* * *$ & NS \\
\hline 18:1 trans- 12 & 0.44 & 0.35 & 0.024 & $* * *$ & NS \\
\hline $18: 1$ trans $-16+$ cis -14 & 0.31 & 0.29 & 0.017 & NS & NS \\
\hline
\end{tabular}

${ }^{1} \mathrm{SED}=$ standard error of difference. Results are mean values of triplicate determination $(\mathrm{n}=288)$.

${ }^{2}$ Probability of significant effects due to type of forage (hay and silage) and ripening time (100 and $\left.180 \mathrm{~d}\right)$.

${ }^{3} \mathrm{VA}=$ vaccenic acid.

${ }^{*} P \leq 0.05 ;{ }^{*} P \leq 0.01 ;{ }^{* * *} P \leq 0.001 ;{ }^{\mathrm{NS}} P>0.05$.

(Nudda et al., 2014). In the present study, we showed that the type of conserved forage - hay or silage - used for sheep feeding affected the cheese fatty acid profile. This could be due to the fatty acid differences observed between the 2 diets. As shown in Table 1, haymaking led to forages with a different fatty acid profile from those produced by ensiling. These results were in accordance with those described by Glasser et al. (2013), who stated that decreases in the PUFA content of silage result from the lipolysis and oxidation of PUFA during the ensiling and drying process. Nevertheless, changes in the fatty acid composition of forage during ensiling could also be attributed to the complex fermentation process that takes place.

The SFA were the predominant fatty acids in cheese, accounting for $72 \%$ of total FAME (Table 3), similar to other reports on sheep cheese fat. The most abundant SFA was palmitic acid $\left(\mathrm{C}_{16: 0}\right)$, followed by stearic acid $\left(\mathrm{C}_{18: 0}\right)$ and myristic acid $\left(\mathrm{C}_{14: 0}\right)$, which represented $64 \%$ of total SFA. Cheese fat is known to contain high proportions of SFA, which has contributed to the negative perceptions of this dairy product. In this regard, $\mathrm{C}_{12: 0}$, $\mathrm{C}_{14: 0}$, and $\mathrm{C}_{16 \cdot 0}$ fatty acids have been linked to the risk of developing coronary heart disease (Lock and Bauman, 2004; Parodi, 2004). However, one of the relevant results of this study was that forage type did not have a significant effect $(P>0.05)$ on the contents of these SFA, and thus did not negatively affect the nutritional profile of sheep cheese fat.

Most of the odd- and branched-chain SFA in dairy fat are synthesized de novo by ruminal bacteria through straight-chain and branched-chain fatty acid synthetas- 
es, suggesting that these fatty acids could be a potential diagnostic tool for rumen function (Fievez et al., 2012). As can be seen in Table 3, there was no significant difference $(P>0.05)$ odd- and branched-chain SFA contents between the different cheeses, showing that diet did not disrupt the sheep gut microbiota. These results indicated that the main differences observed in the fatty acid profiles of the different cheeses, which are described below, were mainly due to the concentrations of these fatty acids or their precursors in the feedstuffs.

The conservation method of forage led to changes in the total amount of trans-MUFA in cheese, modifications that were characterized by significant differences $(P \leq 0.05)$ in trans $\mathrm{C}_{18: 1}$ isomers (Table 4$)$. Considerable concern exists with respect to health risks associated with the consumption of trans-fatty acids; therefore, nutritional guidelines recommend reducing the intake of this type of fatty acids. However, recent reviews make clear that industrial trans fatty acids generated during the hydrogenation of vegetable oils, as trans-10 $\mathrm{C}_{18: 1}$, are different from trans fatty acids produced in the digestive tract of ruminants as VA (trans- $11 \mathrm{C}_{18: 1}$; Ferlay et al., 2017; Gómez-Cortés et al., 2018). In the present study, the amount of trans-10 $\mathrm{C}_{18: 1}$, which has been linked to increases in triglyceride levels, in cheeses manufactured with milk from sheep fed common vetch silage was less than $0.5 \%$ of total FAME. This proportion of trans-10 $\mathrm{C}_{18: 1}$ is lower than that described in other studies in which sheep diets were supplemented with different plant oils or even with extruded linseed (Gómez-Cortés et al., 2009a; Bodas et al., 2010). In all the sheep cheeses studied, the major isomer of trans$\mathrm{C}_{18: 1}$ content was trans- $11 \mathrm{C}_{18: 1}(\mathrm{VA})$. Overall, this fatty acid represented approximately $38 \%$ of total trans- $\mathrm{C}_{18: 1}$ (Table 4). The intake of VA in the human diet is important because this fatty acid can act as a precur-

Table 5. Polyunsaturated fatty acid composition (g/100 g of total FAME) and fatty acid indices of cheese fat from sheep fed with hay or silage

\begin{tabular}{|c|c|c|c|c|c|}
\hline \multirow[b]{2}{*}{ Variable } & \multicolumn{2}{|c|}{ Type of forage } & \multirow[b]{2}{*}{$\mathrm{SED}^{1}$} & \multicolumn{2}{|c|}{$P$-value ${ }^{2}$} \\
\hline & Hay & Silage & & $\begin{array}{l}\text { Type of } \\
\text { forage }\end{array}$ & Ripening time \\
\hline Total PUFA & 5.42 & 4.61 & 0.122 & $* * *$ & NS \\
\hline$\Sigma$ unconjugated $18: 2$ & 3.86 & 3.23 & 0.103 & $* * *$ & NS \\
\hline $18: 2$ cis -9, trans $-13+$ trans -8, cis -12 & 0.32 & 0.33 & 0.007 & NS & NS \\
\hline $18: 2$ cis -9, trans $-12+$ trans -8, cis -13 & 0.15 & 0.15 & 0.004 & NS & NS \\
\hline $18: 2$ trans -9, cis -12 & 0.03 & 0.03 & 0.002 & NS & NS \\
\hline $18: 2$ trans- 11, cis- 15 & 0.06 & 0.06 & 0.005 & NS & NS \\
\hline 18:2 other trans,trans & 0.19 & 0.18 & 0.007 & NS & NS \\
\hline $18: 2$ cis -9, cis -12 & 3.10 & 2.47 & 0.100 & $* * *$ & NS \\
\hline $18: 2$ cis -9, cis- 15 & 0.02 & 0.02 & 0.003 & NS & NS \\
\hline$\Sigma$ conjugated 18:2 (CLA) & 0.55 & 0.43 & 0.021 & $* * *$ & NS \\
\hline $18: 2$ trans -7, cis -9 & 0.05 & 0.05 & 0.004 & NS & NS \\
\hline 18:2 cis-9,trans- $11\left(\mathrm{RA}^{3}\right)$ & 0.44 & 0.33 & 0.020 & $* * *$ & NS \\
\hline $18: 2$ trans -9, cis -11 & 0.01 & 0.01 & 0.001 & NS & NS \\
\hline $18: 2$ trans -10, cis -12 & 0.01 & 0.01 & 0.001 & NS & NS \\
\hline $18: 2$ trans -11, trans -13 & 0.01 & 0.01 & 0.004 & NS & NS \\
\hline $\begin{array}{l}18: 2 \text { trans }-8, \text { trans }-10+\text { trans }-9, \text { trans }-11+ \\
\text { trans }-10, \text { trans }-12\end{array}$ & 0.03 & 0.03 & 0.002 & NS & NS \\
\hline Total 18:2 & 4.42 & 3.66 & 0.112 & $* * *$ & NS \\
\hline $18: 3$ cis- 9, trans- 11, cis- 15 & 0.03 & 0.04 & 0.002 & NS & NS \\
\hline$\Sigma \mathrm{n}-6$ & 3.39 & 2.13 & 0.102 & $* * *$ & NS \\
\hline $18: 3 n-6$ & 0.06 & 0.04 & 0.002 & $* * *$ & NS \\
\hline $20: 2 n-6$ & 0.02 & 0.02 & 0.001 & NS & $* *$ \\
\hline $20: 3 n-6$ & 0.03 & 0.02 & 0.001 & NS & NS \\
\hline $20: 4 n-6$ & 0.17 & 0.16 & 0.006 & NS & NS \\
\hline $22: 4 n-6$ & 0.03 & 0.03 & 0.002 & NS & NS \\
\hline$\Sigma \mathrm{n}-3$ & 0.67 & 0.64 & 0.027 & NS & NS \\
\hline $18: 3 n-3$ & 0.51 & 0.47 & 0.021 & NS & NS \\
\hline $20: 5 n-3$ & 0.04 & 0.04 & 0.002 & NS & NS \\
\hline $22: 5 n-3$ & 0.09 & 0.10 & 0.005 & NS & NS \\
\hline $22: 6 n-3$ & 0.03 & 0.03 & 0.003 & NS & NS \\
\hline
\end{tabular}

${ }^{1} \mathrm{SED}=$ standard error of difference. Results are mean values of triplicate determinations $(\mathrm{n}=288)$.

${ }^{2}$ Probability of significant effects due to type of forage (hay and silage) and ripening time (100 and $180 \mathrm{~d}$ ).

${ }^{3} \mathrm{RA}=$ rumenic acid

${ }^{* *} P \leq 0.01 ;{ }^{* *} P \leq 0.001 ;{ }^{\mathrm{NS}} P>0.05$. 
sor for the endogenous synthesis of cis-9,trans-11 $\mathrm{C}_{18: 2}$ (rumenic acid, RA) through the stearoyl CoA enzyme (Turpeinen et al., 2002), providing the health-beneficial effects attributed to this CLA isomer. Intake of dietary VA itself can provide other health benefits beyond those associated with RA (Field et al., 2009; GómezCortés et al., 2018). In the current study, cheeses made with milk from sheep fed hay showed 35\% more VA than cheeses made with milk from sheep fed silage. Vaccenic acid is produced directly in the rumen by the incomplete biohydrogenation of linoleic acid (Lock and Bauman, 2004). Therefore, the differences observed in VA proportions of cheeses could be associated with the higher content of $\mathrm{C}_{18: 2}$ fatty acids detected in the hay diet compared with the silage diet (Table 1).

The conserved forage type used for sheep feeding modified the total PUFA content of cheese (Table 5). Feeding common vetch hay led to 1.17 -fold more PUFA in sheep milk cheeses. These differences in PUFA contents of cheeses were partly due to the significantly higher $(P \leq 0.001)$ proportion of linoleic acid $\left(\mathrm{C}_{18: 2}\right.$ cis-9,cis-12) detected in cheeses made with milk from sheep fed with hay compared with the silage counterparts. The source of linoleic acid in milk is the diet; therefore, the content of this fatty acid in the cheeses studied could be the result of the effect of the conservation method, because ensiling generated a lower proportion of $\mathrm{C}_{18: 2}$ fatty acids in the forage compared with haymaking.

Within the PUFA, the CLA group has special interest. In the present study, 8 CLA isomers were identified; RA was the major isomer detected in all the cheeses, representing $>75 \%$ of total CLA content, followed by trans-7,cis-9 $\mathrm{C}_{18: 2}$ (Table 5). The amount of total CLA in cheeses made with milk from sheep fed hay was 1.28-fold higher than that in cheeses made with milk from sheep fed silage. Because the other CLA isomers did not change with the type of forage, these effects are exclusively associated with RA. This isomer is of great interest because it has been linked with several functional properties, principally anticarcinogenic and antiatherogenic effects (Ferlay et al., 2017; GómezCortés et al., 2018). Therefore, an increased RA content in cheeses would be positive from a nutritional perspective. Despite this, the amount of CLA in the cheeses was lower than described in other studies for cheeses made with milk from sheep fed fresh forages (Addis et al., 2005; Renobales et al., 2012). This could be because fresh forages contain more $\alpha$-linolenic acid than conserved forages. $\alpha$-Linolenic acid is precursor of $\mathrm{VA}$ in the rumen, which is subsequently converted to RA in the mammary gland via $\Delta^{9}$-desaturase (Bichi et al., 2012). It has been also shown that fresh forages can enhance $\Delta^{9}$-desaturase activity in the mammary gland (Renna et al., 2012).

Most of the $\mathrm{n}-3$ fatty acids in cheese fats belonged to $\alpha$-linolenic acid $\left(\mathrm{C}_{18: 3}\right.$ cis-9,cis-12,cis-15). The percentage detected (about $0.50 \%$ of total fatty acids, Table 5 ) was slightly higher than the levels currently reported for this foodstuff in the literature. The rest of the n-3 fatty acids were detected in very low amounts. Forage type did not have a significant effect $(P>0.05)$ on $\alpha$-linolenic acid content of cheese and, therefore, would not affect negatively the nutritional value of sheep cheese fat.

The results of the present study confirmed that there was no variation in fatty acid profile related to the ripening process itself; therefore, differences in the fatty acid profiles of cheese were mainly due to the effect of type of conserved forage used for sheep feeding.

\section{CONCLUSIONS}

Conserved forages are often used by farmers for sheep feeding because the availability and quality of fresh pasture throughout the year can be affected by several factors, and conserved forages are a low-cost alternative to diet supplementation strategies. We showed for the first time that 2 common methods of forage conservation, haymaking and ensiling, affected the fatty acid profile of milk from commercial flocks fed with these type of forages and could lead to changes in the nutritional value of cheese fat. In contrast, ripening period did not affect the fatty acid profile of sheep milk cheese.

\section{ACKNOWLEDGMENTS}

This work was supported by the Ministerio de Economía y Competitividad (Project AGL2016-75159C2-2-R; Madrid, Spain) and the Instituto Nacional de Investigación y Tecnología Agraria y Alimentaria (Project TA2014-00069-CO2-02; Madrid, Spain). The authors also acknowledge Entrepinares S.A.U. Company (Valladolid, Spain) for the help in the cheese-making trials.

\section{REFERENCES}

Addis, M., A. Cabiddu, G. Pinna, M. Decandia, G. Piredda, A. Pirisi, and G. Molle. 2005. Milk and cheese fatty acid composition in sheep fed Mediterranean forages with reference to conjugated linoleic acid cis-9,trans-11. J. Dairy Sci. 88:3443-3454.

Agarwal, S., J. R. Powers, B. G. Swanson, S. Chen, and S. Clark. 2008. Influence of salt/moisture ratio on starter culture and lactate crystal formation. J. Dairy Sci. 91:2967-2980.

Aii, T., S. Takahashi, M. Kurihura, and S. Kume. 1988. The effects of Italian ryegrass hay, haylage and fresh Italian ryegrass on the fatty acid composition of cow's milk. Jpn. J. Zootech. Sci. 59:718-724. 
AOAC. 1980a. Hydrogen-ion activity (pH). 13th ed. W. Horwitz, ed. Association of Official Analytical Chemists, Washington, DC.

AOAC. 1980b. Acidity in cheese. 13th ed. W. Horwitz, ed. Association of Official Analytical Chemists, Washington, DC.

AOAC. 1990a. Fat (crude) or ether extract in animal feed. 15th ed. K. Helrich, ed. Association of Official Analytical Chemists, Arlington, VA.

AOAC. 1990b. Chloride (total) in cheese Volhard method. 15th ed. K. Helrich, ed. Association of Official Analytical Chemists, Arlington, VA.

Balthazar, C. F., T. C. Pimentel, L. L. Ferrão, C. N. Almada, A. Santillo, M. Albenzio, N. Mollakhalili, A. M. Mortazavian, J. S. Nascimento, M. C. Silva, M. Q. Freitas, A. S. Sant'Ana, D. Granato, and A. G. Cruz. 2017. Sheep Milk: Physicochemical characteristics and relevance for functional food development. Compr. Rev. Food Sci. Food Saf. 16:247-262.

Bichi, E., P. G. Toral, G. Hervás, P. Frutos, P. Gómez-Cortés, M. Juárez, and M. A. de la Fuente. 2012. Inhibition of $\Delta$ 9-desaturase activity with sterculic acid: Effect on the endogenous synthesis of cis-9 18:1 and cis-9, trans-11 18:2 in dairy sheep. J. Dairy Sci. 95:5242-5252.

Bodas, R., T. Manso, A. R. Mantecón, M. Juárez, M. A. De la Fuente, and P. Gómez-Cortés. 2010. Comparison of the fatty acid profiles in cheeses from ewes fed diets supplemented with different plant oils. J. Agric. Food Chem. 58:10493-10502.

Buccioni, A., M. Decandia, S. Minieri, G. Molle, and A. Cabiddu. 2012. Lipid metabolism in the rumen: New insights on lipolysis and biohydrogenation with an emphasis on the role of endogenous plant factors. Anim. Feed Sci. Technol. 174:1-25.

Buccioni, A., S. Rapaccini, M. Antongiovanni, S. Minieri, G. Conte, and M. Mele. 2010. Conjugated linoleic acid and C18:1 isomers content in milk fat of sheep and their transfer to Pecorino Toscano cheese. Int. Dairy J. 20:190-194.

Cabiddu, A., M. Decandia, M. Addis, G. Piredda, A. Pirisi, and G. Molle. 2005. Managing Mediterranean pastures in order to enhance the level of beneficial fatty acids in sheep milk. Small Rumin. Res. 59:169-180.

Cividini, A., and M. Simčič. 2015. Fatty acids profile in milk of Bovec sheep fed in the stable or grazed in different pastures. Poljoprivreda (Osijek) 21:109-112.

de la Fuente, M. A., V. Rodríguez-Pino, and M. Juárez. 2015. Use of an extremely polar $100-\mathrm{m}$ column in combination with a cyanoalkyl polysiloxane column to complement the study of milk fats with different fatty acid profiles. Int. Dairy J. 47:52-63.

Dewhurst, R. J., K. J. Shingfield, M. R. F. Lee, and N. D. Scollan 2006. Increasing the concentrations of beneficial polyunsaturated fatty acids in milk produced by dairy cows in high-forage systems. Anim. Feed Sci. Technol. 131:168-206.

dos Santos, K. M. O., M. A. D. Bomfim, A. D. S. Vieira, S. D. Benevides, S. M. I. Saad, F. C. A. Buriti, and A. S. Egito. 2012. Probiotic caprine Coalho cheese naturally enriched in conjugated linoleic acid as a vehicle for Lactobacillus acidophilus and beneficial fatty acids. Int. Dairy J. 24:107-112.

Ferlay, A., L. Bernard, A. Meynadier, and C. Malpuech-Brugère. 2017. Production of trans and conjugated fatty acids in dairy ruminants and their putative effects on human health: A review. Biochimie 141:107-120.

Field, C. J., H. H. Blewett, S. Proctor, and D. Vine. 2009. Human health benefits of vaccenic acid. Appl. Physiol. Nutr. Metab. 34:979-991.

Fievez, V., E. Colman, J. M. Castro-Montoya, I. Stefanov, and B. Vlaeminck. 2012. Milk odd- and branched-chain fatty acids as biomarkers of rumen function-An update. Anim. Feed Sci. Technol. $172: 51-65$

FIL-IDF. 2001. Milk-Determination of nitrogen content-Part 1: Kjeldahl method. International Dairy Federation, Brussels, Belgium.

FIL-IDF. 2004. Cheese and processed cheese-Determination of the total solids content. International Dairy Federation, Brussels, Belgium.
FIL-IDF. 2008. Cheese-Determination of fat content-Van Gulik method. International Dairy Federation, Brussels, Belgium.

Glasser, F., M. Doreau, G. Maxin, and R. Baumont. 2013. Fat and fatty acid content and composition of forages: A meta-analysis. Anim. Feed Sci. Technol. 185:19-34.

Gómez-Cortés, P., A. Bach, P. Luna, M. Juárez, and M. A. de la Fuente. 2009a. Effects of extruded linseed supplementation on n-3 fatty acids and conjugated linoleic acid in milk and cheese from ewes. J. Dairy Sci. 92:4122-4134.

Gómez-Cortés, P., P. Frutos, A. R. Mantecón, M. Juárez, M. A. De la Fuente, and G. Hervás. 2009b. Effect of the supplementation of grazing dairy ewes with a cereal concentrate on animal performance, milk fatty acid profile and rumen fermentation. J. Dairy Sci. 92:3964-3972.

Gómez-Cortés, P., M. Juárez, and M. A. de la Fuente. 2018. Milk fatty acids and potential health benefits: An updated vision. Trends Food Sci. Technol. 81:1-9.

ISO. 1999. ISO 6496: 1999. Animal feeding stuffs-Determination of moisture and other volatile matter content. International Organization for Standardization, Geneva, Switzerland.

ISO. 2002. ISO 5984: 2002. Animal feeding stuffs-Determination of crude ash. International Organization for Standardization, Geneva, Switzerland.

Kalač, P., and E. Samková. 2010. The effects of feeding various forages on fatty acid composition of bovine milk fat: A review. Czech J. Anim. Sci. 55:521-537.

Lin, H., T. D. Boylston, L. O. Luedecke, and T. D. Shultz. 1999. Conjugated linoleic acid content of Cheddar-type cheeses as affected by processing. J. Food Sci. 64:874-878.

Lock, A. L., and D. E. Bauman. 2004. Modifying milk fat composition of dairy cows to enhance fatty acids beneficial to human health. Lipids 39:1197-1206.

McSweeney, P. L. H., and M. J. Sousa. 2000. Biochemical pathways for the production of flavour compounds in cheeses during ripening: A review. Lait 80:293-324.

Nudda, A., G. Battacone, O. Boaventura Neto, A. Cannas, A. H. D. Francesconi, A. S. Atzori, G. Pulina, A. Nudda, G. Battacone, O. Boaventura Neto, and A. Cannas. 2014. Feeding strategies to design the fatty acid profile of sheep milk and cheese. Rev. Bras. Zootec. 43:445-456.

Nudda, A., M. A. McGuire, G. Battacone, and G. Pulina. 2005. Seasonal variation in conjugated linoleic acid and vaccenic acid in milk fat of sheep and its transfer to cheese and ricotta. J. Dairy Sci. 88:1311-1319.

Parodi, P. W. 2004. Milk fat in human nutrition. Aust. J. Dairy Technol. 59:3-59.

Renes, E., P. Gómez-Cortés, M. A. de la Fuente, D. M. Linares, M. E. Tornadijo, and J. M. Fresno. 2019. CLA-producing adjunct cultures improve the nutritional value of sheep cheese fat. Food Res. Int. 116:819-826.

Renna, M., P. Cornale, C. Lussiana, V. Malfatto, A. Mimosi, and L. M. Battaglini. 2012. Fatty acid profile of milk from goats fed diets with different levels of conserved and fresh forages. Int. J. Dairy Technol. 65:201-207.

Renobales, de M., G. Amores, J. Arranz, M. Virto, L. J. R. Barrón, M. A. Bustamante, J. C. Ruiz de Gordoa, A. I. Nájera, I. Valdivielso, E. Abilleira, I. Beltrán de Heredia, F. J. Pérez-Elortondo, R. Ruiz, M. Albisu, and N. Mandaluniz. 2012. Part-time grazing improves sheep milk production and its nutritional characteristics. Food Chem. 130:90-96

Ryhänen, E. L., K. Tallavaara, J. M. Griinari, S. Jaakkola, K. J. Mantere-Alhonen, and S. Shingfield. 2005. Production of conjugated linoleic acid enriched milk and dairy products from cows receiving grass silage supplemented with a cereal-based concentrate containing rapeseed oil. Int. Dairy J. 15:207-217.

Sales-Campos, H., P. Reis de Souza, B. Crema Peghini, J. Santana da Silva, and C. Ribeiro Cardoso. 2013. An overview of the modulatory effects of oleic acid in health and disease. Mini Rev. Med. Chem. 13:201-210. 
Shingfield, K. J., M. Bonnet, and N. D. Scollan. 2013. Recent developments in altering the fatty acid composition of ruminant-derived foods. Animal 7:132-162.

Thiex, N. J., H. Manson, S. Andersson, and J. A. Persson. 2002. Determination of crude protein in animal feed, forage, grain, and oilseeds by using block digestion with a copper catalyst and steam distillation into boric acid: Collaborative study. J. AOAC Int. 85:309-317.

Thomas, T. D., and K. N. Pearce. 1981. Influence of salt on lactose fermentation and proteolysis in Cheddar cheese. Dairy Sci. Technol. 16:253-259.
Turpeinen, A. M., M. Mutanen, A. Aro, I. Salminen, S. Basu, D. L. Palmquist, and J. M. Griinari. 2002. Bioconversion of vaccenic acid to conjugated linoleic acid in humans. Am. J. Clin. Nutr. 76:504-510.

Van Soest, P. J., J. B. Robertson, and B. A. Lewis. 1991. Methods for dietary fiber, neutral detergent fiber, and nonstarch polysaccharides in relation to animal nutrition. J. Dairy Sci. 74:3583-3597. 